\title{
Seroprevalence of Hydatidosis in Camels of Assuit Province, Egypt
}

\author{
Ahmed Kamal Dyab Haemaei ${ }^{1 \star}$, Ghada M Mohamed ${ }^{2}$ and Osama H Abd Ella ${ }^{3}$ \\ ${ }^{I}$ Department of Medical Parasitology, Faculty of Medicine, Assiut University, Egypt \\ ${ }^{2}$ First researcher, Animal Health Research Institute, Assiut Laboratory, Egypt \\ ${ }^{3}$ Department of Medical Parasitology, Faculty of Medicine, South Valley University, Egypt
}

Article Info

\author{
*Corresponding author: \\ Ahmed Kamal Dyab Haemaei \\ Professor and Head \\ Department of Medical Parasitology \\ Faculty of Medicine (71526) \\ Assiut University, Egypt \\ Tel: 00201018614645 \\ Fax: 0020882350177 \\ E-mail: ahmedsaf2001@yahoo.com; \\ ahmed2015@aun.edu.eg
}

\section{Received: March 16, 2017 \\ Accepted: May 5, 2017 \\ Published: May 12, 2017}

Citation: Dyab AK, Mohamed GM, Abdella OH. Seroprevalence of Hydatidosis in Camels of Assuit Province, Egypt. Madridge J Vaccines. 2017; 1(1): 5-8.

doi: 10.18689/mjv-1000102

Copyright: ( $\odot 2017$ The Author(s). This work is licensed under a Creative Commons Attribution 4.0 International License, which permits unrestricted use, distribution, and reproduction in any medium, provided the original work is properly cited.

Published by Madridge Publishers

\begin{abstract}
The present investigation was conducted (during PM examination of the slaughtered carcasses) to assess the prevalence of hydatidosis in camels sacrificed in Assuit Governorate Egypt and to evaluate the sensitivity and specificity of Indirect Enzyme-linked immunosorbent assay (ELISA) in identifying camels infected with hydatid cysts before slaughtering using antigens were precipitated from HCF. Hydatid cyst count and characterization were conducted based on routine meat inspection. Slaughterhouse samples of 200 camels were collected through weekly visits. Hydatid cysts in livers, lungs and kidneys were detected and counted, also the fertility rate of the cysts was examined. Out of these, 12 (6\%) were found to harbour hydatid cyst, in livers $9(75 \%)$, lungs $2(17 \%)$ and kidney $1(8 \%)$.On the other side, fertile cysts $5(41.7 \%)$ were found more frequently in livers $4(33.3 \%)$ than in lungs $1(8.3 \%)$, while sterile cysts7(58.3\%) found in livers, lungs and kidneys $5(41.7 \%), 1(8.1)$ and $1(8.3 \%)$ respectively. In addition to PM examination, Enzymelinked immunosorbent assay test (ELISA) was developed to the same camels for serological detection of hydatid cyst infection but in alive state. 16(8\%) of the 200 camels were found harbouring hydatid cysts were serologically positive when screened for hydatidosis by ELISA test. Four animals (2\%) out of the 188 non-infected camels gave serologically positive result. It is suggested that the ELISA as a serological assay, is a valuable method with high diagnostic efficiency for serodiagnosis of hydatid disease. The public health importance of hydatidosis as well as some recommended measures for controlling of the disease were discussed.
\end{abstract}

Keywords: Diagnosis; Hydatid cyst; ELISA P.M; Camels.

\section{Introduction}

The main source of animal protein is livestock and their products. Parasitism is one of the main constraints limiting livestock production. Mortality of animals from parasitic diseases may not be alarming at time but their direct effects in terms of reduced milk, meat, wool, hide production, infertility and loss of stamina of working animals [1].

Cystic Echinococcosis (CE) is a chronic zoonotic parasitic helminthic disease due to infection with the larval stage (hydatid) of the dog tapeworm Echinococcus granulosus. The parasite has a global distribution but is particularly prevalent in rural areas where it is transmitted in a cycle between the dog, the definitive host and man, sheep, camel, and other ruminants act as intermediate hosts causing major economic and health problems [2]. The life cycle of Echinococcus granulosus involves domestic and wild carnivores as definitive hosts, which are infected by the ingestion of the hydatid cyst, which may be present in the tissues of infected animals with viable protoscoleces producing adult 
stage in the intestine. Dogs are the main source of infection, although in some areas jackals, hyenas, foxes, and wolves could also play a role as definitive hosts. A wide range of domestic, wild mammals and humans act as intermediate hosts for this parasite where the larval stages (hydatid cyst) develop after ingesting the eggs [3]. Accidental rupture of hydatid cyst during trauma can provoke severe anaphylactic reactions in human [4]. Cystic echinococcosis accounts for more than $95 \%$ of the estimated 2-3 million human global cases affected by Echinococcus parasites [5]. Hydatid cysts can be found in many tissues, most often in the liver, lung, mediastinum, peritoneum and nearly every site of the body [6]. In animals, hydatid cyst usually remain as asymptomatic disease producing no clinical symptoms and its course is slow. In domastic animals diagnosis is almost made during postmortem, small unilocular cysts are usually not diagnosed in young animals until middle life or later [7]. Animals infected with this cysts often suffer from reductions in live weight gain, in milk yielding, in the fertility rates, in the value of wool or other products [8]. On the other hand the main clinical symptoms in humans include liver dysfunction, lung problems, ascites, abdominal pain, hepatomegaly, splenomegaly, central nervous system disorders [7]. The larva of Echinococcus granulosus, may grow for 5 to 20 years without being detected. Surgical excision of the cyst is the only effective treatment, but in many cases the disease recurs because the contents of th $5 \mathrm{e}$ cyst may be escape during the operation [8]. Identification of sensitive and specific methods for immunodiagnosis of hydatid cysts is affected by the degree of sensitivity and specificity of the used antigens. These methods are able to exclude false negative or false positive reactions caused by infection with other cestoda or even other helminthes [9]. Immunodiagnostic techniques such as Enzyme-linked immunosorbent assay (ELISA) is used for the diagnosis of hydatidosis in human and animals. This serological test provides extremely useful diagnostic method for the disease [10]. The current study aimed to assess the usefulness of ELISA test for serodiagnosis of cystic echinococcosis in camel infected with hydatid cysts before slaughtering and to assess the prevalence of hydatidosis in camels sacrificed in Assuit governorate. Hydatid cyst count and characterization were conducted based on routine meat inspection.

\section{Materials and Methods}

The camels used in this study came from different location of Assuit Governorate Egypt, to the abattoirs (Assuit and Bany-ady abattoirs). After slaughtering, the animals were examined for the presence of hydatid cyst in the livers, lungs and other organs. Infected animals were recorded and the infected organs were collected. Any cyst found was collected in normal saline. The surface of a randomly selected cyst of each infected organ was sterilized by alcoholic-iodine solution to reduce intra-cystic pressure, and then the cyst was penetrated by a needle and cut given with scalpel and blade, then the content (fluid and germinal layers) was transferred into sterile container and examined microscopically for the presence of protoscolices. The viability of protoscolices was determined by using eosin exclusion $10 \%$ solution. This test for cell death, viable protoscolices do not take eosin stain [11].

\section{Serological survey}

Indirect enzyme-linked immunosorbent assay (ELISA) was developed for serological detection of hydatid cyst infection in alive camels. (Employed to determine the prevalence of specific antibodies against hydatidosis in sera collected from alive camels). In indircet ELISA kits the wells were coated by hydatid cyst fluid (HCF) antigens were precipitated from HCF [12]. The antigen was prepared to used local antigen which more sensitive and specific. Blood was collected from each animal before slaughtering and allowed to clot for separation of serum. Serum samples were stored at $-20^{\circ} \mathrm{C}$ until examination.

\section{Preparation of antigen}

Two hydatid cyst fluid (HCF) antigens (antigens A and B) were found to be the most immunogenic antigens in HCF [13] [14]. The two antigens were precipitated together from HCF. This was done by adding $2 \mathrm{M}$ phosphotungstic acid and $2 \mathrm{M}$ magnesium chloride solutions to clarified HCF while continuously stirring the mixture. The precipitate formed was suspended in physiological saline [15]. This antigens' solution was used to coat microtitre plates for indirect ELISA which was performed on 200 selected camels sera [16]. ELISA test was done as described by [17] as manufacture directions

\section{Results and Discussion}

Hydatidosis is an important parasitic zoonosis and the disease has been recorded in almost all parts of the world during execution of veterinary inspection in slaughter houses [18]. The results were evident that out of 200 slaughtered camels examined visually and manually by palpation and incision, 12 (6\%) were found harboring hydatid cysts in, livers, lungs and kidneys. Of the total 12 infected, 9 (75\%) had hydatid cysts in the liver, $2(17 \%)$ in the lung, and $1(8 \%)$ found in the kidney. It is indicated that livers and lungs are the most commonly affected organs with hydatid cysts due to the reason that they are the first large capillary fields encountered by the blood born onchosphers. The results of this study revealed that liver is the most commonly affected organ which might be due to the reflection of the route of parasite entry and seem to support the hypothesis of hepatic portal distribution of onchosphers leading firstly to liver infection [19]. The distribution of cysts in different organs based on their sizes. The infection rate increases as the age of animal increases. It was found that aged animals may gain access of infection due to longer exposure than young ones. It was also reported by [20] that, the number of infected eggs ingested by intermediate host is determined by the level of contamination and infectivity of the eggs. Furthermore, the number of eggs that develop into hydatid cysts is controlled by the immune system of the host. The findings of this study revealed that low number of the slaughtered camels were infected with hydatid cysts. The argument behind the lowest 
infection rate was the unique raising system and the feeding management of camel as well as the weak relationship between camel and stray dogs may explain these findings [21]. Confirmed to our results, [22] could not detect hydatid cyst from any of the examined slaughtered camels. Also, some authors recorded nearly similar percentage of hydatid cysts as, [23] (8.8\%) [24] who revealed that the overall annual prevalence rates of camel infection were 5.5\% (1992), 6.1\% (1993), 6.7\% (1994), 8.2\% (1995) and 4.3\% (1996), [25] (4.9\%), [26] (9\%) and [27] (5.5\%). On the other side, the obtained results were lower than that recorded by [28] (20,4\%), [29] who recorded $50 \%$ in Northern of Guinea zone and $55.5 \%$ in Sudan zone, [29] (40\%), [30] (16\%), [31] (20.7\%).

By using HCF Antigen A and B [12] (32.9\%) and [32] (26\%). The high (20est percentage of infection which is mainly attributed to the old age at the animal was slaughtered and examined for the presence of hydatid cysts. It was found that the environmental conditions such as suitable condition for survival of the eggs of E. granulosus and the presence of large number of stray dogs around the raising area of animals are the main factors governing the prevalence rate of hydatidosis in ruminants [21]. In addition, out of the total $12(6 \%)$ cysts collected, 5(41,7\%) were fertile an $16 \mathrm{~d} 7(58.3 \%)$ were sterile cysts. The occurrence of fertile cysts was higher in liver 4(33.3\%) than in lung $1(8.3 \%)$ while the sterile cysts found more frequently in liver $5(41.7 \%)$ than in lung $1(8.3 \%)$ and kidney $1(8.3 \%)$. As far as this study is concerned, the results of fertility were lower than that obtained by [29] (94.5\%), [23] (66.7\%) and [31] (58.2\%). While [30] cited that $6.3 \%$ barber fertile hydatid cyst which seem to be lower than our results. Variation in fertility could be attributed to strain differences in traits such as host and organ preference, development rate, infectivity, pathogenesis and antigenicity and drug resistance [20].

Diagnosis of hydatidosis is still problematic [33]. Serological tests such as immunoelectrophoresis, double diffusion in agar, or indirect hemagglutination are being replaced by more sensitive assay methods such as enzyme-linked immunosorbent assay (ELISA) [34]. ELISA was, highly specific (90\%) for camels natural CE infection [12] and its sensitivity was found to be 98\% [16] Concerning the pre-slaughtered camels, the finding outlined in Table"1" showed that the percentage of hydatidosis by ELISA technique was (8\%). This trend is lower than that recorded by (35) (26.6\%) in local camels, 32\% in imported camels) and EL-Baz (1994) (40\%). The incidence of infection was higher by indirect ELISA technique (8\%) in comparison with the data of P.M examination (6\%). It is clearly evident in Table" 1 " that $4(2 \%)$ animals out of 188 (94\%) non infected camels gave positive results serologically by ELISA. This was agreed with [36] as the difference between sero-diagnosis and PM diagnosis of hydatidosis may be related to presence of small sized hydatid cyst which could not be demonstrated by visual examination or presence of infections in other parts of the body did not accurately investigated. The main problems for the serodiagnosis of cystic echinococcosis are often the unsatisfactory performance of the available tests and the difficulties associated with the standardization of antigenic preparations and techniques [37]. To overcome these drawbacks, highly sensitive and specific antigens and antigenic components derived from different developmental stages of E. granulosus must be available [38] [39] [40].

Table 1: Comparison between results of ELISA and post-mortem examination in diagnosis of Hydatidosis in

\begin{tabular}{|c|c|c|c|c|c|c|c|}
\hline Teat & $\begin{array}{c}{ }^{*} \text { No. of } \\
\text { examined } \\
\text { camels }\end{array}$ & $\begin{array}{l}\text { Infected } \\
\text { animals }\end{array}$ & $\begin{array}{c}\text { Non } \\
\text { Infected } \\
\text { animas }\end{array}$ & $\begin{array}{c}\text { difference } \\
(\%) \text { the }\end{array}$ & $\begin{array}{l}\text { Location } \\
\text { of cysts }\end{array}$ & & \\
\hline \multirow[t]{2}{*}{ EllSA test } & 200 & $\begin{array}{c}16 \\
(8 \%) \\
\end{array}$ & $\begin{array}{c}184 \\
(92 \%) \\
\end{array}$ & & $\begin{array}{l}\text { Kidney } \\
1(8 \%) \\
\end{array}$ & \begin{tabular}{|c|} 
Lung \\
$2(17 \%)$
\end{tabular} & $\begin{array}{c}\text { Liver } \\
9(75 \%) \\
\end{array}$ \\
\hline & & & & $4(2 \%)$ & & & \\
\hline $\begin{array}{c}\text { *P. M. } \\
\text { examination }\end{array}$ & 200 & $\begin{array}{c}12 \\
(6 \%)\end{array}$ & $\begin{array}{c}188 \\
(94 \%)\end{array}$ & & & & \\
\hline
\end{tabular}

*Same animals

In conclusion: The results of this study indicated that hydatidosis is of great public health and economic significance in the governorate of Assuit. Detection of hydatid cysts in the slaughtered camels abattoirs and its improper disposal will act as a source of infection to final host (mainly dog) and transmission to human beings. Accordingly, conducting public campaign is urgently required to control this disease through destruction of stray dogs, prohibiting illegal slaughter of animals outside abattoirs, proper disposal of infected organs, fencing of slaughterhouses and increase awareness of the people on the epidemiology of the disease. Identification of infected animals during their life could facilitate slaughtering them under special control measures which ensure total condemnations of their infected tissues and eliminate the random arrival of the cysts to dog, the matter which play the role to minimize the infection in dogs and wide spread of the diseases. Moreover it is necessary to mention that, control measures of hydatidosis must be carried on parallel to that of human beings, also against the definitive host and the other intermediate ones. It can be also concluded that ELISA should be considered not as an alternative but as a useful addition to the range of immunodiagnostic tests available for serodiagnosis of hydatid

\section{References}

1. Derbala AA, Zayed AA. Prevalence, fertility and viability of cysticercosis and hydatidosis infections in some domestic animals. J. Union Arab Biol. 1997; 7: 109-123.

2. Torgerson PR, Budke C. Echinococcosis: An international public health challenge. Res. Vet. Sci. 2003; 74: 191-202.

3. Seimenis A. Overview of the epidemiological situation on echinococcosis in the Mediterranean region. Acta Trop. 2003; 85: 191-95.

4. Boyano T, Moldenhauer F, Mira J, Joral A, Saiz F. Systemic anaphylaxis due to hepatic hydatid disease. J. Investig Allergol Clinlmmunol. 1994; 4: 158-59.

5. Budke CM. Global socioeconomic impact of cystic echinococcosis. Geospatial Health. 2016; 2: 105-111.

6. Muller R, Muller R. Worms and Human Diseases. CABI International, Oxon, Wallingord, UK. 2002; ISBN: 0851995160: 320.

7. Hassan DA. Future studies on possible differences between E. granulosus substrains through biochemical analysis of electrolyte, lipids and other components of the larval and adult stages of parasite. ph.D. thesis. vet. Parasitology Fac. Vet. Med. Cairo university. 1991.

8. Torgerson PR. Economic effect of echinococcosis. ActaTropica. 2003; 85: 113-18. 
9. Sadjjadi SM, Abidi H, Sarkari B, Izadpanah A, Kazemian S. Evaluation of enzyme linked immunosorbent assay, utilizing native antigen $B$ for serodiagnosis of human hydatidosis. Iran. J. Immunol. 2007; 4(3): 167-72.

10. Rebhandl W, Turnbull J, Felberbauer FX, Tasci E, Puig S, Auer H. Pulmonary echinococcosis (hydatidosis) in children: results of surgical treatment. Pediatr. Pulmonol. 1999; 27: 336-40.

11. Macpherson CNL, French CM, Stevenson P, Karstad L, Arundel J. Hydatid disease in the Turkana District of Kenya. The prevalence of Echinococcus granulosusinfections in dogs and observations on the role of the dog in the life style of the Turkana. Ann. Trop. Med. Parasitol. 1985; (79): 51-61.

12. Ibrahim MM. Study of cystic echinococcosis in slaughtered animals in Al Baha region, SaudiArabia: Interaction between some biotic and abiotic factors. Acta Tropica. 2010; 113:26-33. doi: 10.1016/j.actatropica.2009.08.029

13. Shirazi $S$, Rad R, Bahadorir N. Isolation and purification of Echinococcus granulosus antigen $B$ from hydatid cyst fluid using three different methods. 2016.

14. Toppolo S, Notargiacome S, Profumo E, Franchi C, Oratona E, Rigano R, Siracusona A. Immunological responses to antigen $B$ from Echinococcus granulosus cyst fluid in hydatid patients. Parasite. Immunlolgy. 1996; 18(11): 571-578.

15. Seyed MS, Hassan A, Bahador S, Ahmad I, Sakineh K. Evaluation of Enzyme Linked Immunosorbent Assay, Utilizing Native Antigen B for Serodiagnosis of Human Hydatidosis : Iran. J.Immunol. 2007; 4(3): 167172.

16. Kagiko MM, Gathuma JM, Lindqvist KJ. Serological diagnosis of hydatid disease by enzyme linked immunosorbent assay (ELISA) using partially purified hydatid cyst fluid antigens. Int. J. Zoonoses. 1986; 13(4): 241-5.

17. Gottstein BP, Jacquie S, Bresson H, Eckert J. Improved primary immunodiagnosis of alveolar echinoccosis in human by ELISA using Em2plus antigen. J. Clin. Microbiol. 1993; 31: 373-376.

18. Ashraf $M, K$ Kan $M Z$, Chishti MA. Incidence and pathology of lungs affected with tuberculosis and hydatidoses in sheep and goats. 1987.

19. Schwabe CW. Current status of hydatid disease: a zoonosis of increasing importance ; in: the biology of Echinococcus and hydatid disease. (Edited by: Thompson, R.C.A.) London; UK; George Allen and Univ.: 1986; 81-113.

20. Thompson RCA, Lymbery AJ. The nature, extent and significance of variation within the genus Echinococcus. Adv. Parasitol. 1988; 27: 210258.

21. Abiyot J, Beyene D, Abunna F. Prevalence of hydatidosis in small ruminants and its economic significance in Modjo Modern Export Abattoir, Ethiopia. J. Publ. Health Epidemiol. 2011; 3(10): 454-61.

22. Hikmat SA. Epidemiological study on the prevalence of hydatidosis in slaughtered ruminants in Kerbala Governorate. J. Kerbala Univ. 2012; 10(4): 326-33.

23. Al-Yaman FM, Assaf L, Hailat N, AbdelHafez SK. Prevalence of hydatidosis in slaughtered animals from North Jordan. Ann Trop. Med. Parasitol. 1985; 79(5): 501-506.

24. Haridy FM, Ibrahim BB, Morsy TA. Studies on hydatidosis in slaughtered camels in Egypt. J. Egypt Soc. Parasitol. 1998; 28(3): 673-81.

25. EL-Dakhly KM, Hassan WH, Lotfy HS. Some parasitic and bacterial causes of liver affection in ruminants.Beni-Suef. Vet. Med. J. 2007; 5: 62-68.
26. Abdullah AM, Oboegbulem SI, Daneji Al. Incidence of hydatid cyst disease in food animals slaughtered at Sokoto Central Abattoir, Sokoto State, Nigeria. Vet. World. 2011; 4(5): 197-200.

27. Abdulrahman MA, Mosa MB. Some epidemiological and serological studies on hydatidosis in Najran Region. J. of Am. Sci. 2012; 8(12): 918921.

28. AL-Abbassy SN, AL-TAIF KI, Jawad AK, ALsaqur IM. The prevalence of hydatid cysts in slaughtered animals in Iraq. J. Ann. Trop. Med. Parasitol. 1980; 74(2): 185-187.

29. Dada BJO. Teaniasis,cysticercosis andechinococcosis hydatidosis in Nigrria: prevalence of bovine and porcine cysticercosis, and hydatid cyst infection based on joint examination of slaughtered food animals. J. Helminthol. 54(4): 293-297.

30. Haroun EM, Omer OH, Mahmoud OM, Draz A. Serological studies on hydatidosis in camels in Saudi Arabia. Department of Veterinary Medicine, College of Agriculture and Veterinary Medicine. Res. J., Vet. Sci. 2008; 1(1): 71-73.

31. Saeid F, Mohamed MD, Mohamed HR. Occurrence of hydatidosis in camels (Camelus dromedarius) and their potential role in the epidemiology of Echinococcus granulosus in Kerman area, southeast of Iran. Comp. cli.l pathol. 2009; 21(5): 921-927.

32. Hazzaz BK, Mohammad E, AbulHashem M, Omar FM. Prevalence of zoonotic parasitic diseases of domestic animals in different abattoir of Comilla and Brahman Baria region in Bangladesh. Univ.j. zool. Rajshahi. Univ. 2010; (28): 21-25.

33. Sako $Y$, Tappe $D$, Fukuda $K$, Kobayashi $Y$, Itoh $S$, Frosch $M$, et al. Immunochromatographic Test with Recombinant Em18 Antigen for the Follow-Up Study of Alveolar Echinococcosis. Clin. Vaccine Immunol. 2011; 18(8): 1302-1305. doi: 10.1128/CVI.05156-11

34. Virginio VG, Hernandez A, Rott MB, Monteiro KM, Zandonai AF, Nieto A. $A$ set of recombinant antigens from Echinococcus granulosus with potential for use in the immunodiagnosis of human cystic hydatid disease". Clin. Exp. Immunol. 2003; 132: 309-315.

35. Ahmed MS. Advanced concepts in diagnosis of hydatidosis in Human and Living animals. J. of Biological Sci. 2007; 7: 720-728.

36. EL-Baz MA. Some studies on diagnosis of hydatidosis in slaughtered animals. M.V.Sc. thesis Fac. Vet. Cairo University. 1997.

37. Doiz O, Benito R, Sbihi Y, Osuna A, Clavel A, Gomez-Lus R. Western blot applied to the diagnosis and post-treatment monitoring of human hydatidosis. Diag. Microbiol. Infect. Dis. 2011; 41(3): 139-142. doi: 10.1016/S0732-8893(01)00293-0

38. Carmena $D$, Benito $A$, Eraso $E$. Antigens for the immunodiagnosis of Echinococcus granulosus infection. An update. Acta Trop. 2011; 98(1): 74-86. doi: 10.1016/j.actatropica.2006.02.002

39. Anwar AH, Hag AU, Gill SA, Chaudhury AH. Prevalence and fertility ratio of hydatid cyst in slaughtered sheep and goat at Faisalabad Pakistan. Vet. J. 1993; 13: 79-81. doi: 10.4236/aim.2015.54023

40. Ibrahem MM, Rafiei A, Dar FK, Azwai SM, Carter SD, Craig PS Serodiagnosis of cystic echinococcosis in naturally infected camels. Parasitol. 2002; 125(3): 245-251. 